\title{
PENGETAHUAN MASYARAKAT TENTANG DEMAM BERDARAH DENGUE DI DESA MAEN KECAMATAN LIKUPANG TIMUR KABUPATEN MINAHASA UTARA
}

\author{
${ }^{1}$ Indra Setiawan Syarif \\ ${ }^{2}$ Iyone E.T. Siagian \\ ${ }^{2}$ Wulan P.J. Kaunang \\ ${ }^{1}$ Kandidat Skripsi Fakultas Kedokteran Universitas Sam Ratulangi \\ ${ }^{2}$ Bagian Ilmu Kesehatan Masyarakat Fakultas Kedokteran Universitas Sam Ratulangi \\ Manado \\ Email: Indrasetiawansyarif@yahoo.com
}

\begin{abstract}
Dengue hemorrhagic fever (DHF) is an infectious disease caused by the dengue virus. As known, DHF is still one of the potentially infectious disease that can cause an outbreaks / extraordinary events (KLB). The main vector of dengue is Aedes aegypti were found both in Indonesia and other subtropical countries. One of the ways to prevent this disease is to break the chain of disease transmission by mosquito nest eradication program (PSN). This study aimed to determine the knowledge of the community in the village of Maen About Dengue Fever. In this study, the method used is the survey method with a descriptive approach. Furthermore, data collected through interviews using questionnaires. The population is all households in the village Maen totaling 365 households. Numbers of samples is determined by simple random sampling with a sample of 90 households.

From this study it can be concluded that the knowledge of the people in the village Maen About Dengue overall scores $72.2 \%$ and categorized as having good knowledge.
\end{abstract}

Keywords: community, dengue fever, Knowledge, Maen village.

\begin{abstract}
Abstrak: Demam berdarah dengue (DBD) ialah penyakit infeksi yang disebabkan oleh virus dengue. Seperti diketahui bersama, DBD masih merupakan salah satu penyakit menular yang berpotensi wabah / kejadian luar biasa (KLB). Vektor utama DBD ialah aedes aegypti yang ditemukan baik di Indonesia dan negara-negara subtropis lainnya. Salah satu cara mencegah penyakit ini ialah dengan memutus rantai penularan penyakit dengan program pemberantasan sarang nyamuk (PSN). Penelitian ini dimaksudkan untuk mengetahui pengetahuan masyarakat di Desa Maen Tentang Demam Berdarah Dengue. Pada penelitian ini, metode yang digunakan ialah metode survey dengan pendekatan secara deskriptif. Selanjutnya, Pengambilan data dilakukan dengan wawancara menggunakan kuisioner. Populasi ialah seluruh kepala keluarga di desa Maen yang berjumlah 365 KK. Banyak sampel ditetapkan secara simple random sampling dengan jumlah sampel 90 KK. Dari penelitian ini dapat disimpulkan bahwa pengetahuan masyarakat di Desa Maen Tentang Demam Berdarah Dengue secara keseluruhan mendapatkan nilai 72,2\% dan dikategorikan baik.
\end{abstract}

Kata Kunci : demam berdarah dengue, desa Maen, masyarakat, Pengetahuan.

Demam berdarah dengue (DBD) adalah penyakit infeksi yang disebabkan oleh virus dengue, sampai saat ini merupakan salah satu penyakit menular yang telah menim- bulkan kejadian luar biasa/wabah. Penyakit ini dapat menyerang semua orang/golongan umur, tetapi angka tertinggi dari penderita DBD yaitu anak-anak dan tidak ada 
perbedaan jenis kelamin. Penyakit ini biasanya berjangkit di daerah perkotaan karena kepadatan penduduk yang tinggi. Seiring dengan makin lancarnya transportasi menyebabkan masyarakat yang tinggal dipedesaan juga menerima limpahan kenaikan kasus DBD dari kota besar. ${ }^{1}$

Aedes Aegypti merupakan vektor utama dengue di Indonesia. Vektor ini banyak terdapat di tempat-tempat yang biasanya berisi air jernih dan tawar, misalnya bak mandi, drum penampungan air, kaleng bekas, dan lain sebagainya. Perkembangan vektor tersebut berhubungan erat dengan kebiasan masyarakat menampung air untuk kebutuhan sehari-hari, kebersihan lingkungan yang kurang baik dan penyediaan air bersih yang langka. Sampai saat ini vaksin atau obat untuk membasmi DBD secara efektif belum ditemukan. ${ }^{2}$

Peyakit DBD merupakan masalah umum yang semakin membesar di negaranegara subtropik. Penyakit ini merupakan penyakit yang endemik dilebih dari 100 negara termasuk Afrika, Amerika, Mediterranean Timur, Asia Tenggara dan pasific Barat. World Health Organization (WHO) menggambarkan mungkin terdapat 50-100 juta kasus penyakit dengue diseluruh dunia setiap tahun, dimana 250.000-500.000 kasus adalah DBD angka kematian sekitar 24.000 jiwa per tahun. Penyakit DBD pertama kali dicurigai ada di Indonesia pada tahun 1968 tepatnya di kota Surabaya dimana ada 58 orang terinfeksi dan 24 diantaranya meninggal dunia, tetapi konfirmasi virologisnya baru diperoleh pada tahun 1970. Di Sulawesi Utara Penyakit ini pertama kali di temukan pada tahun 1973. Sejak pertama kali di temukan, jumlah kasus menunjukan kecendrungan meningkat baik dalam jumlah maupun wilayah yang terjangkit dan secara sporadik selalu terjadi kejadian luar biasa (KLB) yang setiap tahun.

Pada tahun 1998 terjadi KLB DBD terbesar, dengan insiden rate (IR) 35,19 per 100.000 penduduk dan case fatality rate (CFR) 2\% . Pada tahun 1999 IR, menurun tajam sebesar 10,17\%, namun tahun-tahun berikutnya IR cenderung meningkat yaitu
15,99 pada tahun 2000, 21,66\% pada tahun 2001 19,24\% pada tahun 2002, dan 23,87\% pada tahun 2003. Saat ini jumlah penderita DBD di kabupaten Minahasa pada tahun 2008 sebanyak 101 penderita, yang meninggal 3 orang. Tahun 2009 sebanyak 115 penderita. Tahun 2010 sebayak 264 penderita, yang meninggal sebanyak 4 orang. ${ }^{3}$

Di Sulawesi Utara berdasarkan data Kemenkes Tahun 2011 menempati urutan 16 angka IR yaitu 6,25\% angka ini masih di bawah target IR, yaitu $\leq 55 \%$. Untuk angka CFR, Sulawesi Utara menempati urutan 3 tertinggi yaitu 3,51\% ini tentunya masih di atas target CFR yaitu $\leq 1 \%$. Saat ini jumlah DBD di kabupaten Minahasa pada tahun 2008 sebanyak 101 penderita, yang meninggal 3 orang. Tahun 2009 sebanyak 115 penderita. Tahun 2010 sebanyak 264 penderita yang meninggal 4 orang. ${ }^{4}$

Data terakhir pada Puskesmas Kecamatan Likupang Tahun 2009,2010, dan 2011 tidak didapatkan penderita DBD, akan tetapi pada Tahun 2012 tepatnya di dalam bulan oktober, sudah didapatkan penderita sebanyak 3 orang, dan tidak ada yang meninggal.

Berdasarkan data diatas tersebut penulis mengambil topik DBD, karena masih merupakan permasalahan kesehatan di Kabupten Minahasa Utara dan satusatunya cara untuk mencegah penyakit ini adalah dengan pemberantasan vektor. Dipilihnya Puskesmas Likupang karena akses yang relatif mudah, selain itu juga data kasus DBD di Puskesmas Likupang dalam sebulan terakhir ini relatif terjadi peningkatan dalam jumlah kasus.

\section{Rumusan Masalah}

Bagaimanakah pengetahuan masyarakat tentang penyakit DBD di Desa Maen Kecamatan Likupang Timur Kabupaten Minahasa Utara?

\section{Tujuan Penelitian}

Untuk mengetahui pengetahuan dan pencegahan masyarakat tentang DBD di Desa Maen Kecamatan Likupang. 


\section{METODE PENELITIAN}

Penelitian ini merupakan penelitian deskriptif dengan menggunakan metode survey. Tempat penelitian ini Desa Maen Kecamatan Likupang Timur Kabupaten

Minahasa Utara dengan waktu peneltian selama bulan November 2012 hingga Januari 2013. Populasi pada penelitian ini yaitu semua kepala keluarga yang ada di desa Maen kecamatan Likupang Kabupaten Minahasa Utara yang berjumlah 365 kepala keluarga yang terbagi dalam 6 Jaga. Adapun yang menjadi responden adalah bapak atau ibu, sedangkan Sampel pada penelitian ini ditentukan dengan menggunakan rumus Snedecor cochran: ${ }^{5} \quad \mathrm{n}=\frac{4 \mathrm{pq}}{\mathrm{L}^{2}}$ dimana, $\mathrm{n}=$ jumlah sampel awal, $\mathrm{p}=$ sifat suatu keadaan dalam persen dianggap 50\%, $\mathrm{q}=$ $100 \%-\mathrm{p}, \quad \mathrm{L}=$ derajat ketepatan yang digunakan $10 \%$ dan selanjutnya $n 1=\frac{n}{1+\frac{n}{N}}$ yakni : $\mathrm{n} 1$ = jumlah sampel sebenarnya $\mathrm{N}=$ jumplah populasi, Sehingga jumlah nilai:

$\mathrm{n}=\frac{4 \times 50 \% \times 50 \%}{(10 \%)^{2}}=100, \mathrm{n} 1=\frac{100}{1+\frac{100}{365}}=78,74$ maka jumlah sampel minimal yang akan diambil adalah 79 di tambah $10 \%$ sehingga menjadi 90 sampel. Selanjutnya untuk menentukan sampel terpilih didistribusi pada tiap lingkungan yang terdapat di Desa Maen dengan cara sebagai berikut:

$\frac{\text { jumla } h \text { unit sampel }}{\text { total unit sampel }} x$ sampel yang dibutuhkan

1. Jaga I $: \frac{75}{365} \times 90=18$ keluarga

2. Jaga II $: \frac{75}{365} \times 90=18$ keluarga

3. Jaga III $: \frac{49}{365} \times 90=12$ keluarga

4. Jaga IV $: \frac{58}{365} \times 90=14$ keluarga

5. Jaga $\mathrm{V}: \frac{51}{365} \times 90=14$ keluarga

6. Jaga VI : $\frac{57}{365} \times 90=14$ keluarga

Sehingga jumlah keseluruhan sampel sebanyak 90 sampel dan untuk menentukan sampel yang terpilih digunakan tekhnik pengambilan sampling simple random sampling yang dilakukan secara ordinal, sehingga anggota sampel dipilih berdasarkan urutan tertentu. ${ }^{22}$

\section{Variabel Penelitian}

Pada variabel penelitian terbagi atas 2 yakni yang pertama tentang Karekteristik responden yang didalamnya terdapat Pendidikan dan Pekerjaan dan yang kedua tentang Pengetahuan responden yaitu pengetahuan mengenai informasi tentang DBD, cara penyebaran penyakit DBD, Bahaya DBD, tempat berkembang biak nyamuk DBD, waktu nyamuk DBD biasa menggigit, gejala penyakit DBD serta pencegahan penyakit DBD.

\section{Definisi Operasional}

Untuk definisi operasional pendidikan ialah tingkat pendidikan formil terakhir responden, Pekerjaan ialah sumber mata pencarian responden baik pegawai negeri sipil ataupun swasta, pengetahuan ialah pengetahuan masyarakat tentang penyakit DBD di Desa Mean Kecamatan Likupang Timur, pengetahuan dianggap baik jika pada saat wawancara responden menjawab "YA" lebih dari $50 \%$ dan buruk jika reponden menjawab "TIDAK" lebih dari $50 \%$, Masyarakat ialah penduduk yang tinggal di Desa Maen Kecamatan Likupang dan diambil sebagai responden, selanjutnya DBD ialah penyakit menular yang disebabkan oleh virus dengue dan ditularkan melalui gigitan nyamuk aedes aegypti yang ditandai dengan demam mendadak tinggi selama 2-7 hari tanpa penyebab yang jelas disertai perdarahan pada kulit (bintik-bintik merah), perdarahan hidung, perdarahan gusi, muntah darah ataupun berak darah dan yang terakhir vektor DBD ialah jenis nyamuk yang dapat membawa virus dengue adalah penyebab penyakit demam berdarah.

\section{Cara Kerja}

Pada penelitian ini wawancara dengan menggunakan kuesioner yang berisi pernyataan yang telah disusun digunakan 
sebagai alat pengumpulan data. Selanjutnya, untuk Pengolahan data dilakukan dengan menggunakan sistem tabulasi dan dianalisa berdasarkan hasil persentasi. Penilaian terhadap variabel didasarkan pada rata-rata jawaban yang benar menurut komponen pengetahuan dimana diukur berdasarkan skala guttman.

\section{HASIL PENELITIAN DAN BAHASAN}

Desa Maen ialah suatu desa yang berada di Kecamatan Likupang Timur Kabupaten Minahasa Utara. Luas wilayah \pm 700 Ha dan terletak pada ketinggian 10 meter dari permukaan laut dengan suhu rata-rata berkisar 30-40 derajat celcius. Di sebelah utara desa Maen berbatasan dengan laut Sulawesi, di sebelah timur dengan desa Marinso, di sebelah selatan dengan desa Winori dan di sebelah barat berbatasan dengan desa Winoru. Penduduk desa Maen berjumlah 1.400 jiwa yang terdiri dari pria 731 jiwa dan wanita 669 jiwa yang tedapat didalam 365 kepala keluarga.

Tabel 1. Distribusi kepala keluarga desa Maen

\begin{tabular}{cccc}
\hline No & Jaga & N & Presentase ( \% ) \\
\hline 1 & I & 75 & 20,55 \\
2 & II & 75 & 20,55 \\
3 & III & 49 & 13,43 \\
4 & IV & 58 & 15,89 \\
5 & V & 51 & 13,97 \\
6 & VI & 57 & 15,62 \\
Jumlah & & 365 & 100 \\
\hline
\end{tabular}

Tabel 2. Distribusi berdasarkan pendidikan terakhir

\begin{tabular}{ccc}
\hline Jenis pendidikan & $\mathbf{N}$ & $\mathbf{\%}$ \\
\hline Tidak Sekolah & 1 & 1,1 \\
SD & 43 & 47,8 \\
SMP & 26 & 28,9 \\
SMA & 18 & 20,0 \\
PT & 2 & 2,2 \\
Total & 90 & 100,0 \\
\hline
\end{tabular}

Sesuai dengan tabel diatas jaga I dan II memiliki jumlah penduduk paling banyak dengan jumlah 75 KK (20,55\%), jaga IV memiliki 58 KK (15,89\%), jaga VI memiliki 57 KK (15,62\%), jaga V memiliki 51 KK (13,97\%), dan jaga III memiliki 49 KK $(13,43 \%)$.

Tingkat pendidikan dapat memengaruhi pola pikir dan daya cerna seseorang. Semakin tinggi pendidikan seseorang, semakin tinggi pula informasi yang dapat diserap dan tingginya informasi yang diserap mempengaruhi pengetahuannya. Orang yang berpendidikan tinggi lebih besar kepeduliannya terhadap masalah kesehatan. ${ }^{6}$

Pada tabel 02 di atas menunjukan pendidikan terakhir responden yang terbanyak ialah SD 43 responden $(47,8 \%)$, SMP 26 responden (28,9\%), SMA 18 responden (20,0\%), PT 2 responden (2,2\%), dan Tidak Sekolah 1 responden $(1,1 \%)$. Dari data dilihat bahwa tingkat terbanyak ialah SD dengan 43 responden (47,8\%). Hal ini tentu akan berpengaruh pada pola pikir dan daya cerna serta penyerapan informasi yang diberikan dan akan berdampak buruk pada pengetahuan responden.

Tabel 3. Distribusi berdasarkan pekerjaan.

\begin{tabular}{ccc}
\hline Jenis pekerjaan & $\mathbf{N}$ & $\mathbf{\%}$ \\
\hline Tidak kerja & 36 & 40,0 \\
Petani & 20 & 22,2 \\
Swasta & 21 & 23,3 \\
Nelayan & 10 & 11,1 \\
PNS & 3 & 3,3 \\
Total & 90 & 100,0 \\
\hline
\end{tabular}

Pada tabel 03 dapat di lihat pekerjaan responden yang paling banyak ialah Tidak Bekerja 36 responden (40,0\%), Swasta 21 responden (22,2\%), Petani 20 responden (22,2\%), Nelayan 10 responden $(11,1 \%)$, dan Pegawai Negeri Sipil (PNS) 3 responden $(3,3 \%)$.

Berkaitan dengan pekerjaan, hampir serupa kaitannya dengan tingkat pendidikan. Responden yang bekerja sebagai PNS pendidikan terendah ialah SMA. Sehinngga, PNS memeiliki lebih banyak 
sumber informasi dan juga daya serap yang lebih baik. Pada tabel 03 dapat dilihat responden terbanyak ialah tidak bekerja yakni $40 \%$, sedangkan PNS hanya 3,3\% hal ini tentulah akan berpengaruh buruk pada pengetahuan masyrakat tentang DBD.

Tabel 4. Apakah responden pernah mendapat informasi tentang penyakit DBD.

\begin{tabular}{ccc}
\hline Jawaban & $\mathbf{N}$ & $\mathbf{\%}$ \\
\hline Ya & 64 & 71,1 \\
Tidak & 26 & 28,9 \\
Total & 90 & 100,0 \\
\hline
\end{tabular}

Berdasarkan Tabel 04 di atas dapat diketahui bahwa hampir seluruh warga desa Maen pernah mendapatkan informasi tentang penyakit DBD yaitu 64 responden $(71,1 \%)$, dan sisanya yang belum pernah mendapatkan informasi tentang penyakit DBD ada 26 responden (28,9\%). Responden banyak mendapatkan informasi dari media elektronik dan media cetak, juga dari petugas-petugas kesehatan setempat. Ini menunjukan keaktifan petugas-petugas kesehatan daerah setempat dan peran serta media cetak dan elektronik dalam memberi pengetahuan dan informasi kepada warga masyrakat tentang penyakit DBD ini. Secara langsung maupun tidak langsung, akan berdampak baik pada pengetahuan masyarakat khususnya tentang DBD.

Tabel 5. Pengetahuan masyarakat tentang cara penyebaran DBD.

\begin{tabular}{ccc}
\hline Jawaban & $\mathbf{N}$ & $\mathbf{\%}$ \\
\hline Ya & 52 & 57,8 \\
Tidak & 38 & 42,2 \\
Total & 90 & 100,0 \\
\hline
\end{tabular}

Cara penularan penyakit DBD melalui gigitan nyamuk aedes aegypti meskipun dapat juga ditularkan oleh aedes albopictus betina yang sebelumnya telah membawa virus dalam tubuhnya dari penderita demam berdarah lain. ${ }^{7}$
Dari jawaban responden pada tabel 05 di atas dapat dilihat ada 52 responden (57,8\%), menjawab tahu tentang cara penyebaran penyakit ini sedangkan sisanya 38 responden (42,2\%) menjawab tidak tahu.. Hal ini menjelaskan walaupun tingkat pendidikan di desa Maen tidak baik tapi masyarakat mempunyai daya cerna serta daya serap yang baik tentang cara penyebaran DBD dan akan sangat berguna bagi masyarakat sebagai dasar pencegahan penyakit DBD ini.

Tabel 6. Pengetahuan responden terhadap bahaya penyakit DBD

\begin{tabular}{ccc}
\hline Jawaban & $\mathbf{N}$ & $\mathbf{\%}$ \\
\hline Ya & 69 & 76,7 \\
Tidak & 21 & 23,3 \\
Total & 90 & 100,0 \\
\hline
\end{tabular}

Komplikasi yang tidak umum dari demam berdarah adalah acute pancreatitis seperti kasus yang dilaporkan di colombia, acute pancreatitis yang terjadi pada pasien berhubungan dengan Diabetes Militus Tipe 1 dan penyakit ginjal yang sudah dalam tahap hemdodialisis. ${ }^{8}$ Sesuai dengan tabel 06 di atas dapat diketahui bahwa lebih dari $70 \%$ menjawab mengetahui bahaya penyakit DBD yaitu, 69 responden (76,7\%), dan sisanya 21 responden (23,3\%) menjawab tidak. Untuk pengetahuan responden tentang bahaya DBD sudah baik, ada $76,7 \%$ yang tahu bahaya dari penyakit DBD ini. Hal ini tentu akan sangat berguna bagi masyarakat untuk mencegah keadaan darurat medik seperti syok, atau bahkan kematian.

Tabel 7. Pengetahuan responden tentang tempat berkembang biak nyamuk DBD.

\begin{tabular}{ccc}
\hline Jawaban & $\mathbf{N}$ & $\mathbf{\%}$ \\
\hline Ya & 68 & 75,6 \\
Tidak & 22 & 24,4 \\
Total & 90 & 100,0 \\
\hline
\end{tabular}


Berdasarkan tabel 07 di atas, responden yang mengetahui tempat berkembang biak nyamuk DBD ada 68 responden (75,6\%), dan yang menjawab tidak mengetahui tempat berkembang biak nyamuk DBD 22 responden $(24,4 \%)$.

Nyamuk Demam Berdarah dewasa lebih memilih untuk beristrahat di tempat gelap. Tempat istrahat favorit berada di bawah tempat tidur, di dalam lemari pakaian, di ruang gelap dan tenang, bahkan pakaian atau perabot. Nyamuk aedes aegypti setelah menggigit (menghisap darah) dan selama menunggu proses pematangan telur beristrahat di tempat yang gelap, lembab, dan kurang angin. ${ }^{9}$ Untuk pengetahuan responden tentang tempat berkembang biak nyamuk DBD sudah baik, dari 90 responden ada 68 responden yang tahu. Pengetahuan ini sangat bermanfaat bagi masyarakat untuk melakukan pencegahan, dalam hal ini untuk menjaga kerapihan dan kebersihan agar rumah masyarakat tidak menjadi tempat berkumpulnya nyamuk DBD.

Tabel 8. Pengetahuan reponden tentang waktu kapan nyamuk DBD biasa menggigit.

\begin{tabular}{ccc}
\hline Jawaban & $\mathbf{N}$ & $\mathbf{\%}$ \\
\hline Ya & 79 & 87,8 \\
Tidak & 11 & 12,2 \\
\hline
\end{tabular}

Sesuai dengan tabel 08 di atas dapat dilihat bahwa 79 responden (87,8\%) mengetahui kapan waktu nyamuk DBD menggigit dan sisanya 11 responden $(12,2 \%)$ menjawab tidak mengetahui kapan nyamuk DBD menggigit.

Tabel 9. Pengetahuan responden tentang gejala penyakit DBD.

\begin{tabular}{ccc}
\hline Jawaban & $\mathbf{N}$ & $\mathbf{\%}$ \\
\hline Ya & 70 & 77,8 \\
Tidak & 20 & 22,2 \\
\hline
\end{tabular}

\begin{tabular}{ccc}
\hline Total & 90 & 100,0 \\
\hline Gejala-gejala & penyakit & demam
\end{tabular}
berdarah adalah Mendadak panas tinggi selama 2-7 hari, tampak lemas dan lesu, seringkali ulu hati terasa nyeri' tampak bintik-bintik merah pada kulit, dan panas tidak turun dengan obat penurun panas atau kompres dingin. ${ }^{10}$

Dari tabel 09 di atas dapat diketahui lebih dari $70 \%$ atau tepatnya 77,8\% responden yang mengetahui tentang gejala DBD. Pengetahuan ini baik bagi masyarakat. Agar, masyarakat ada kesiapan dalam melakukan pertolongan pada penderita, sehingga dapat mencegah penderita dari keadaan- keadaan klinis yang semakin memberatkan.

Tabel 10. Apakah menurut responden penyakit DBD bisa dicegah.

\begin{tabular}{ccc}
\hline Jawaban & $\mathbf{N}$ & $\mathbf{\%}$ \\
\hline Ya & 83 & 92,2 \\
Tidak & 7 & 7,8 \\
Total & 90 & 100,0 \\
\hline
\end{tabular}

Berdasarkan tabel 10 diatas dapat diketahui bahwa pengetahuan responden baik. Terbukti ada, 83 responden (92,2\%) mengetahui penyakit DBD dapat di cegah, dan sisanya hanya 7 responden $(7,8 \%)$ yang menjawab tidak mengetahui apakah penyakit DBD dapat dicegah

Tabel 11. Apakah anda responden mendapatkan informasi tentang pencegahan penyakit DBD.

\begin{tabular}{ccc}
\hline Jawaban & $\mathbf{N}$ & $\mathbf{\%}$ \\
\hline Ya & 62 & 68,9 \\
Tidak & 28 & 31,1 \\
Total & 90 & 100,0 \\
\hline
\end{tabular}

Dari tabel 11 menunjukan bahwa 62 responden (68,9\%) pernah mendapatkan informasi tentang pencegahan penyakit DBD dan sisanya 28 responden (31,1\%) belum pernah mendapatkan informasi 
tentang pencegahan penyakit DBD. Hal ini tentu sangat baik bagi masyarakat untuk melakukan pencegahan penyakit DBD. Seperti pada penelitian yang dilakukan di Kabupaten Bayan Provinsi Banten di dapatkan simpulan bahwa tingkat pengetahuan warga tentang PSN meningkat setelah dilakukan penyuluhan. ${ }^{11}$

Tabel 12. Pengetahuan responden tentang $3 \mathrm{M}$

\begin{tabular}{ccc}
\hline Jawaban & $\mathbf{N}$ & $\mathbf{\%}$ \\
\hline Ya & 69 & 76,7 \\
Tidak & 21 & 23,3 \\
Total & 90 & 100,0 \\
\hline
\end{tabular}

Pencegahan DBD paling baik yang dapat dilakukan yaitu dengan fogging (pengasapan), larvasidasi, dan Pemberantasan Sarang Nyamuk (PSN) dengan cara 3M yakni, Menguras tempattempat penampungan air, menutup rapatrapat tempat penampungan air, dan menguburkan barang-barang bekas yang dapat menampung air hujan seperti kaleng bekas, plastik bekas, dan lain-lain. ${ }^{33}$ Pada tabel 12 di atas diketahui bahwa 69 responden $(76,7 \%)$ yang megetahui tentang $3 \mathrm{M}$ dan sisanya 21 responden (23,3\%) tidak mengetahui. Pengetahuan ini sudah baik karena lebih dari $75 \%$ responden tahu tentang 3M. Pencegahan tentang 3M ialah jenis pencegahan vektor yang paling mudah, murah, dan aman serta mempunyai nilai keberhasilan tinggi yang dapat dlikakukan masyarakat. ${ }^{12}$

Tabel 13. Pengetahuan responden tentang bubuk abate

\begin{tabular}{ccc}
\hline Jawaban & $\mathbf{N}$ & $\mathbf{\%}$ \\
\hline Ya & 34 & 37,8 \\
Tidak & 56 & 62,2 \\
Total & 90 & 100,0 \\
\hline
\end{tabular}

Sesuai dengan tabel 13 di atas di ketahui responden yang tidak mengetahui tentang bubuk abate lebih dari $50 \%$ yaitu berjumlah 56 responden (62,2\%), dan sisanya yang mengetahui tentang bubuk abate 34 responden (37,8\%). Untuk mendorong peran serta aktif masyarakat dalam pencegahan dan penanggulangan penyakit DBD, maka perlu upaya-upaya komunikasi, informasi, dan edukasi (KIE), pemasaran sosial dan upaya penyuluhan perlu dilaksanakan secara intensif dan berkesinambungan. Dari hasil diatas hasil yang tidak karena 37, 8\% yang tahu. Hal ini menunjukkan bahwa upaya-upaya KIE oleh petugas harus lebih ditingkatkan.

Untuk mengetahui bagaimana tingkat pengetahuan responden tentang DBD, maka dari data yang didapatkan dari pertanyaan tentang pengetahuan responden terhadap DBD, dilakukan analisis berdasarkan skala Guttman. Persentase jawaban responden yang sudah di tabel 04 sampai tabel 13 kemudian dibagi dengan 10 ( 10 pertanyaan ). Secara keseluruhan tingkat pengetahuan responden tentang penyakit Demam Berdarah dan cara pencegahannya sudah baik. Ini di buktikan dengan lebih dari 50\% responden ( 72,2\% ) menjawab ya. Pengetahuan ini akan sangat berguna untuk dapat mencegah penularan penyakit DBD di masa mendatang.

\section{SIMPULAN}

Berdasarkan hasil penelitian dan pembahasan, maka dapat ditarik kesimpulan sebagai bahwa pengetahuan dan pencegahan masyarakat tentang Demam Berdarah Dengue di Desa Maen Kecamatan Likupang ialah baik.

\section{DAFTAR PUSTAKA}

1. SOEDARMO SP. Masalah Demam Berdarah Dengue di Indonesia. Jakarta: Balai Penerbit FKUI; 2005.

2. Rampengan T, Laurentz. Penyakit Infeksi Pada Anak. EGC, 2005

3. Dinkes Sulut, jumlah penderita DBD di Provinsi Sulawesi Utara tahun 2008-2010

4. Kementrian Kesehatan Republik Indonesia informasi Umum Demam Berdarah Dengue. Ditjen PP \& PL.2011. diunduh dari http://www.pppl.depkes.go.id/_ 
asset/_download/INFORMASI_UMUM_D BD_2011.pdf.

5. Tjokronegoro A,Sudarso S. Metodologi penelitian bidang kedokteran, Jakarta: balai Penerbit FKUI; 2007

6. Wati WE. Beberapa faktor yang berhubungan dengan kejadian demam berdarah dengue (DBD) di kelurahan Ploso Kecamatan Pacitan.2009. Diunduh dari: http://etd.eprints.ums.ac.id/5988/1/j410050 022.pdf. Diakses pada tanggal 3 januari 2013. Pencegahan dan pemberantasan Demam Berdarah Dengue (DBD)di Indonesia. Direktorat Jenderal Pengendalian Penyakit dan Penyehatan Lingkungan Departemen Kesehatan Republik Indonesia: 2005.

7. Pencegahan dan pemberantasan Demam Berdarah Dengue (DBD)di Indonesia. Direktorat Jenderal Pengendalian Penyakit dan Penyehatan Lingkungan Departemen Kesehatan Republik Indonesia: 2005.

8. Martinez AFH, Fontal GRG. Dengue Hemorrhagicfever complicated by pancreatitis. [serial online].2011[cited 2011 mar 14]. Available from: www.ncbi.nhm.org.

9. Cahyati WH. Suharyo. Dinamika Aedes Aegypti sebagai vektor penyakit. 2011. Diakses dari: http://repository.ipb.ac.id/ bidstream/handle/123456789/52989/daftar $\% 20$ pustaka.pdf?sequence $=11$.

10. Wandra T, Winarno. Pemberantasan sarang nyamuk demam berdarah dengue (PSN DBD).2006. Jakarta; Depertemen Kesehatan RI.

11. Sungkar S, Wintia R, Kurniawan A. Pengaruh penyuluhan terhadap tingkat pengetahuan masyarakat dan kepadatan aedes aegypti di Kecamatan Bayan provinsi Banten. Makara, Kesehatan, vol 14, NO.2, desember 2010:81-85.2010. diunduh dari: http:/journal.ac.id/upload/ artikel/688-1391-1-SM.pdf.

12. Santoso. hubungan pengetahuan sikap dan perilaku (PSP)masyarakat terhadap vektor DBD di kota Palembang provinsi sumatera selatan. Diunduh dari www.ekologi.litbang. depkes.go.id/data/vol7/santoso/1santoso.pdf. 